\title{
Food Shortages, Hunger, and Famines in the USSR, 1928-33
}

\author{
Nicolas Werth \\ Institut d'histoire du temps présent, Centre national de la recherche scientifique
}

\begin{abstract}
This paper examines policies implemented in stages from 1928 and the multi-causal phenomena that resulted in the deaths of some 6.5 to 7 million people, the majority in Ukraine and the Kuban as well as Kazakhstan, during the man-made Soviet famines of the early 1930s. These famines took on distinctively separate trajectories after the autumn of 1932 when Stalin singled out Ukraine, the largest grain-producing region of the USSR. The Kazakh famine resulted from the devastation of the traditional nomadic Kazakh economy in a misguided effort to make that region a main source of meat for the Soviet Union. Other regionsnotably the Middle Volga and Central Chernozem Regions-also suffered. These events were largely driven by Soviet attempts to make the countryside a domestic colony that would provide food resources for the country's accelerated industrialization. This is particularly evident in the manner Soviet authorities rationed and distributed food.
\end{abstract}

Keywords: Soviet, Famines, Kazakh, Ukraine, Stalin

Since the pioneering works of Robert Conquest and James Mace $S$ compelled historians of the Soviet Union to tackle the question of the "man-made" famines of the early 1930s, an impressive body of knowledge has accumulated on these tragic and murderous events. On the basis of a wealth of new sources, historians have been able to reconstruct and to contextualize the policies-that is, the background context-for these famines, which killed some 6.5 to 7 million people, including an estimated 4.2 million in Ukraine and the Kuban, 1.3 to 1.5 million in Kazakhstan, and more than a million in the rest of the Soviet Union.

It is now evident that these major famines, preceded by food shortages, hunger, scarcity, and localized famines, were the result of a general policy implemented by stages from the beginning of 1928. Famines do not occur overnight. They are complex, multi-causal phenomena involving factors such as meteorology (which plays a significant role in most "classical" famines, much less so in the "man-made" famines of Communist regimes), the general state of health of agriculture, relationships between the state and the peasantry, between town and countryside, and between the strata of rural society, and, above all, in Communist regimes, politics. 
The first stage of the process that led to the murderous famines of 1931-33 was the destruction of the market for agricultural products and a return to the system of mandatory procurements at fixed prices that Stalin and his associates launched in January 1928-the infamous "Ural-Siberian method." For urban dwellers this meant immediate severe food shortages, a sharp rise in food prices, and the reintroduction of rationing of bread in the winter of 1928-29 and of meat the following year. For peasants, this turn was marked by the arrest of tens of thousands of grain and meat traders, compulsory procurements, mass repressions against "speculation" and "hoarding" (on the basis of articles 61 and 107 of the Soviet penal code), massive fines (the also infamous piatikratka, which was five times the yearly agricultural tax), and the selling off and confiscation of peasant property and estates. In 1929, before the launching of the collectivization drive, 100,000 farms in Soviet Ukraine, 50,000 in the Middle and Lower Volga regions, 40,000 in the North Caucasus, and 20,000 in Western Siberia were confiscated (Danilov and Berelowich 44-49; Maksudov 128).

This development heralded imminent famine, the memory of which was omnipresent. Although the NEP is sometimes presented as a kind of golden age for the peasantry, it lasted no more than three years (1925-27). Recently published archival documents indicate that the terrible and wellknown famines of 1921-22 had been followed by two "hungry years" in the rural USSR, stretching from Ukraine to the Volga, Western Siberia, and Northern Kazakhstan, which were hit by a drought that led to the mass starvation of millions and the death of hundreds of thousands (Danilov and Berelowich 36-38). In many parts of the country, the peasant economy remained extremely fragile and vulnerable.

The second and decisive stage leading to the famines of the early $1930 \mathrm{~s}$ was launched during the winter of 1929-30. Forced collectivization resulted in the expropriation of peasants' land, horses, agricultural implements, and most of their domestic livestock, thus allowing the state to levy an unprecedented tribute in the form of grain and livestock procurements. This forced collectivization led to a phenomenon with huge, long-term consequences that Danilov termed raskrestianivanie (de-peasantization, to be clearly differentiated from the well-known raskulachivanie [dekulakization] emphasized by the regime itself, which singled out a small minority of the victims of collectivization). Raskrestianivanie was nothing less than an "anthropological revolution" that shook the foundations of peasant identity. The total confiscation of land and livestock from village communities, the harsh restrictions on ownership of domestic animals, and the peasants' loss of control over the distribution of the harvest reduced them to second-class citizens, stripping them of all confidence in the future and the ability to improve their situation by their own efforts. As a result, 
the peasants' traditional work ethic was replaced by a culture of evading work, performing tasks to a bare minimum, and general apathy and moral degradation. The Soviet famines shared a number of similarities as a result of this general policy, but they were also profoundly different from one other. (That is why historians studying these phenomena should refer to them in the plural.)

The famines in Soviet Ukraine and the Kuban, which Ukrainian and Western historians have more thoroughly researched than the other famines, had a clear and distinct trajectory after the autumn of 1932, when the Stalinist leadership purposefully aggravated widespread scarcities and local famines in order to achieve precise political goals, following on Stalin's elaboration of his "national interpretation" of the grain requisition crisis and his singling out of Ukraine as a "unique" national republic whose party had been infiltrated by "Ukrainian nationalists and Petliurites" (Martin 273307). (It is generally acknowledged that between the spring of 1929, when the OGPU reported the first cases of death by starvation, and the summer of 1932 approximately 200,000 people died of starvation in Ukraine, while several millions experienced severe food shortages and hunger.) A vicious, repressive Chekist campaign was launched against "Ukrainian nationalism," targeting the intellectual, religious, and political elites of the Ukrainian nation-some 200,000 people were arrested by the state's security organs in the Ukrainian SSR in 1932-33, a number comparable only to the 270,000 arrests in Ukraine during the Great Terror of 1937-38-at the same time as deliberate punitive actions were taken against the Ukrainian peasantry. Instructions ordering house-to-house searches for "hidden grain" paved the way for the confiscation of all foodstuffs under the pretext of "fining" reluctant peasants, collective farms, villages, and even whole districts that did not meet the grain- and meat-procurement plans. The situation was deliberately aggravated by the blockade of Ukrainian and Kuban villages, aimed at stopping the flight of starving "peasants" (the quotation marks are Stalin's own from his now famous secret telegram dated 22 January 1933). ${ }^{1}$ These deadly measures led to a famine unprecedented in its magnitude and intensity: between January and July 1933, at the peak of the Holodomor, between 15,000 and 20,000 people died every day, in silence and total abandonment.

The Kazakh famine developed in a specific colonial, frontier society with its own unique background and history. For the Stalinist leadership,

1 The full text of this document appears in Danilov, Manning, and Viola 3: 634-35. 
Kazakhstan did not constitute an acute political or national problem. Nevertheless, the Kazakh herders, who raised the largest amount of livestock in the USSR and were designated in 1930 to be the main providers of meat to Soviet urban dwellers, suffered the consequences of the Stalinist "revolution from above" more acutely than any other social or national group. Between thirty-three and thirty-eight percent of them disappeared during the famine. The way in which this murderous famine developed in 1931 and 1932 was, in many ways, different from the course of the famine in Ukraine and the Kuban that took place between the autumn of 1932 and the summer of 1933. The Kazakh famine was the direct but unplanned result of the total destruction of the nomadic and semi-nomadic Kazakh economy; it was aggravated by the strong anti-Kazakh prejudices of local officials and by the traditional conflict between Slavic peasant colonists and Kazakh herders in a society deeply divided in terms of social, economic, and cultural development (See Pianciola 2008 and 2009). Niccolò Pianciola and Sarah Cameron develop these points in this volume, so I will not go further into this case.

The third epicentre of famine was the Lower and Middle Volga and Central Chernozem Regions, a major and thus strategic grain-providing area. It accounted for approximately 20-22 percent of the state's grain procurement, compared with the 46-48 percent provided by Ukraine and the North Caucasus, the 6-8 percent by Western Siberia, the 4-5 percent by the Urals, and the 4 percent by Bashkiria and Tatarstan. Hundreds of thousands-as many as 700,000 according to Viktor Kondrashin-died from famine in the Volga and Central Chernozem Regions as a result of the extraordinarily harsh measures taken there (as in Ukraine and the Kuban), such as the infamous "blacklisting" of collective farms, villages, and sometimes even whole raions that did not "fulfill the plan." Nevertheless, as noted in Danilov's last article before his death, even Pavel Postyshev, who led the extraordinary commission sent in December 1932 to the lower Volga Region to "take grain," acted in a much less brutal way than Viacheslav Molotov or Lazar Kaganovich, who were sent two months earlier to Ukraine and the Kuban as the heads of similar extraordinary commissions (Danilov and Zelenin 97-110). Postyshev, who would later act ruthlessly in Ukraine after his nomination as second secretary of the $\mathrm{CP}(\mathrm{B}) \mathrm{U}$ in January 1933, even softened the most repressive measures local officials proposed in the lower Volga Region. Unlike in Ukraine, there was clearly no national issue here, no major political threat coming from a national movement supposedly linked with émigré or foreign countries. Although very high, the death rate (up to five percent of the total population in the lower Volga Region) never reached the staggering levels that occurred in regions populated by Ukrainians (where the losses represented 
ten to twelve percent of the total population, and much more in some rural areas).

But famine also struck beyond its epicentres. A close reading of OGPU reports clearly indicates that local famines, starvation, scarcity, and hunger affected a number of regions not only during the years 1931-33, but also during the entire 1928-33 period. Every spring from 1928 onwards, OGPU reports mention "food shortages," "consumption of food surrogates," "hunger," "cases of swelling and death from starvation," and "pockets of famine" in the Ural Region, Western Siberia, Far-Eastern Siberia, Belarus, the Western Region, the Northern Region, Bashkiria, and Tatarstan, as well as in most of the traditional grain-consuming oblasts of central and northern Russia, such as Yaroslavl, Kaluga, Kostroma, Riazan, IvanovoVoznesensk, Pskov, Leningrad, and Vologda (Danilov and Berelowich 368402). Those oblasts, which had not been singled out in 1930 as "areas of total collectivization," were clearly not "strategic" on the "procurement front." However, their already fragile agricultural situation quickly degraded. "Individual peasants" who refused to join collective farms were strangled by huge taxes, impoverished by mandatory selling or confiscation of their cattle, and deprived of the traditional spring loan-in-kind granted in hard times by their "richer neighbours," who had been "dekulakized" and were no longer there to help them. As for collective farmers, they were stuck in miserable kolkhozes with no horses or draft animals, but nevertheless were forced to submit, to quote a report of June 1931 from a remote raion in Riazan oblast, to "excesses and deviations by local activists who had gone a little too far in the previous collection campaign" (GARF, $\mathrm{f}$. 1235 , op. 2 d. 1030, l. 14). The lack of local studies and the limited information conveyed in the OGPU svodki (field reports) make it difficult to draw a precise geography or assess the number of victims of those still largely unknown local famines.

Let us take one example-that of the vast Ural Region studied by Gijs Kessler (Kessler 117-29). This industrial and agricultural region (which "brought in" 4-5 percent of the state's grain procurements) contributed an increase of 60 percent of grain and meat procurements between 1928 and 1932, while grain production fell by 35 percent, and livestock by 55 percent (figures that put this region in the "average" range in comparison with other Soviet regions). If we look at places mentioned in the OGPU svodki as "experiencing food difficulties" during the spring of 1930, 1931, and 1932 or being "famine-stricken" (golodaiushchie) from the end of 1932 until the summer of 1933, it appears that many were located on or near railway lines. In those areas, taking grain and shipping it out were easiest for procurement brigades; and railway lines also concentrated masses of hungry people moving around in desperate search of food. Therefore it can 
be reasonably assumed that a great part of the deaths registered in these "pockets of famine" were related to migrants who had died "on the road." It also appears that the areas stricken by famine in 1933 were grouped in a circle stretching approximately 100 kilometres from the provincial capital of Sverdlovsk, with hardly any cases of starvation reported for the districts in its immediate vicinity. This clearly reflects the effects of the system of internal passports and residence permits that had been introduced in Sverdlovsk-as in a number of other important cities or strategically important industrial towns or construction sites-in the spring of 1933. The issuing of passports and residence permits in the so-called "regime areas" was a process of social cleansing in which "undesirable elements" were denied residence and expelled. The introduction of the internal passport and residence permit (propiska) was aimed at ridding strategic urban and industrial centres of peasants in search of food and of "hangerson" to the rationing system. People expelled from "regime towns" could not settle within a 100-kilometre zone around those centres. This might explain the remarkable "famine-free" circle around Sverdlovsk as well as the geography of some of the other famine-stricken areas into which the expelled and, more generally, migrant and vagrant people streamed in search of scarce food resources.

This example raises two major issues directly related to the geography and sociology of the famine: the town/countryside issue and social stratification by the Stalinist state based on the "productive usefulness for the state" of different categories of population, a process Elena Osokina coined as the "hierarchy of consumption" (ierarkhiia potrebleniia), developed from the Leninist principle of "he who does not work shall not eat" as well as on a new, highly differentiated "scale of value" of Soviet subjects resting on the economic benefit each of them could bring to the state (Osokina). In a time of hunger and famine, this "hierarchy" in fact meant much more: it brutally divided those whose survival was ensured from those who were sacrificed and left to die.

In the course of implementing the practical experience of "socialist construction," the Stalinist regime transformed the relation between town and countryside, the latter becoming a sort of domestic colony from which resources were extracted for accelerated and reckless industrialization. While peasants were deprived of almost everything and submitted to a forced acculturation ("de-peasantization"), urban dwellers, especially the residents of capital cities and the largest industrial centres, enjoyed a minimal protection thanks to the ration-card system. They thus suffered "only" from malnutrition and hunger (except in some extreme cases, particularly in a number of small- and middle-sized towns in Ukraine, the North Caucasus, and the Volga Region where thousands of city dwellers 
died of starvation in 1933). It should be noted that during the years 192833 the urban inhabitants' standard of living and level of consumption dropped dramatically: according to official reports about "industrial workers' budgets," the consumption of meat, milk, butter, eggs, and fat fell by an astounding 75-90 percent between 1927 and 1933.

Despite this huge and unprecedented degradation, desperate peasants (some twelve to thirteen million during the First Five-Year Plan!) fled to the towns and thus contributed to a long-lasting "ruralization" of the cities, a phenomenon Moshe Lewin underscored long ago (Lewin 311-15). In order to stop this massive peasant out-migration, in the first half of 1933 the government introduced the internal-passport and residence-permit system.

Peasants living in the most strategic grain-procurement areas and herders in Kazakhstan were, undoubtedly, the main famine victims. But people also died of starvation in a number of towns. According to the first results of the pioneering Harvard Ukrainian Research Institute's Digital Atlas of Ukraine project, it appears that rural areas constituted ninety-two percent of the estimated 3.9 million excess deaths from famine. The highest excess mortality occurred in central Ukraine in a sort of heart-shaped area formed by Kyiv, Dnipropetrovsk, and Kharkiv oblasts. In contrast, the fewest excess deaths took place in the districts adjacent to Soviet Ukraine's western border-in the epicentre of peasant unrest during the "March 1930 fever" (Viola 132-80), where the authorities brought in food; and in the Donbas, a strategic industrial region with a large Russian-speaking working class. However, eight percent of the excess deaths (more than 300,000) transpired in urban areas, mostly in small- or middle-sized towns such as Berdychiv, Proskuriv, Fastiv (aka Khvastiv), Uman, Zhytomyr, and Bila Tserkva, where most of the population, consisting of self-employed craftsmen and workers in small "non-essential" factories (many of them Jews), were classified as those receiving the "third category" of rationing, which was clearly insufficient in providing the vital minimum for survival. As many reports admitted, "workers in small factories and small towns supposed to receive category-three rations are not supplied in practice and have to manage with 100-150 grams of bread per day and nothing else" (Podkur and Vasyl'iev 357-58). Many people-kustari (self-employed craftspeople) and other so-called "elements of the non-organized sector," but also secondary-school pupils and tekhnikum students-were simply excluded from the benefits of the "centralized rationing system" and had to survive on food they managed to buy at exorbitant market prices. In Odesa, for example, the number of people entitled to ration cards fell from 470,000 in September 1932 to 360,000 six months later (Pyrih 704). In some small towns, the mortality rate rose in the spring of 1933 to eight times the average: in Berdychiv (with a population of some 60,000), the GPU reported 
no fewer than 800 deaths (mostly of Jews) in April 1933, that is, an annual death rate of sixteen percent (Podkur and Vasyl'iev 388).

By contrast, better supplied were large, strategically important (both for political and social reasons) cities (Kyiv, Kharkiv), industrial regions (the Donbas), large enterprises, priority construction sites, and railroads. Consequently, the death toll in those urban/industrial oases was considerably lower than the national average, except for the many peasant migrants who died in or around that "promised land." GPU and Party authorities were obviously worried about industrial workers' strong dissatisfaction with the regime at strategically important factories, mines, and railways. In order to avoid total disruption of the railroads by striking hungry railway workers, the first secretary of the $\mathrm{CP}(\mathrm{B}) \mathrm{U}$ in Vinnytsia Oblast, for example, at times ordered the distribution of extra food allowances and thus acted as a "little Stalin" in his fiefdom. (Let us recall Stalin's decision, in the form of the All-Union Politburo's secret resolution of 8 April 1933, to allow workers in Kharkiv to buy five pounds of flour at state prices per family at the height of the famine.) (Podkur and Vasyl'iev 430; Pyrih 812).

Although to a lesser degree than in Ukraine, many small and middlesized cities in other Soviet republics experienced not only food shortages but also widespread hunger and even deaths from starvation. Among those that did, Barysaŭ and Homel in Belarus, Shuia, Vichuga, and Teikovo in Russia's Ivanovo Oblast, and Votkinsk in the Urals Region are best known because of the "hunger strikes" and "hunger riots" that took place there (see Rossman). Those disturbances (volynki), strikes, and riots were usually a desperate reaction to the removal of population categories from the centralized state system of food supply because the government deemed them less important in terms of their "productive usefulness for the state."

After the destruction of private trade (which during NEP represented more than eighty percent of total retail trade), followed immediately (in the spring of 1928) by food shortages in the cities, the state had to assume responsibility for supplying bread and other foodstuffs to city residents, whose numbers grew with every year. As the food situation worsened at the end of 1928, local authorities introduced the first ration cards, a measure approved by the All-Union Politburo on 6 December 1928. Because recipients of the ration cards-first for bread and, later, from the summer of 1930, for meat and other products (butter, groats, sugar, fish, oil, etc.) - were required to redeem them at designated stores at various unannounced times, city residents were forced to expend much time and energy standing in long queues, often without receiving anything at all. Ration cards were issued for a growing number of categories, depending on the state's perception of each citizen's contribution to the "building of 
socialism." An extremely complex and centralized hierarchical system took shape. By 1931 it was comprised of four components:

1. City categories. The "special and first-category list" included Moscow, Leningrad, the republican capitals, and the main industrial cities and industrial sites of strategically important economic regions such as the Donbas, the Urals, Western Siberia, and the emerging Kuzbass. The second and third categories included the other "less important" cities.

2. Occupational categories. Industrial and railroad workers were better treated than other employees, white-collar workers, or members of the intelligentsia. Craftspeople, self-employed individuals, and the few remaining members of the "liberal professions" stood at the bottom of this category, while secret-police staff and high- and middle-ranking Party members stood at the very top, on a special list.

3. Status in the family unit. Employed persons were entitled to higher rations than their dependent children and elderly relatives.

4. The type of workplace in relation to the "global project of industrialization of the country." Miners and workers in heavy metallurgical plants and steel mills received higher rations than people working in textile, food, or light-industry factories. According to the same "logic of industrial pragmatism" (Osokina), teachers in industrial schools and institutes were better fed than teachers working in "classic" institutes, and schoolteachers in rural areas stood at the bottom of this category. In addition, prestigious enterprises were allowed to set up private plots or "kitchen gardens" for their workers and employees, which in a time of acute food shortages and scarcity could significantly improve diets and even save lives (Osokina 11436).

The level and quality of urban residents' diets depended, of course, not only on state rationing, which supplied only a very small proportion of essential needs (often bread and hardly anything else for the lowest categories). Urban residents were thus compelled to buy food at high prices in the state-run shops (kommercheskie magaziny) or at even higher prices on the "free market." As the situation worsened-the overall number of people on the rationing system reached the staggering figure of forty million at the end of 1932, compared to the fourteen million ration cards distributed in 1929-central and local authorities regularly proceeded to exclude "superfluous people" from the rationing system: dependent family members, including children (this measure triggered most of the strikes and disturbances I have mentioned) and people included in the lowest categories, who were entitled to receive (which did not mean that they actually did) a mere 100-200 grams of bread per day.

In this complex stratification, which reflected a new, crude, and cynical relationship between the state and its subjects, two categories of pariahs 
languished at the very bottom: (1) the "special resettlers" (spetspereselentsy), a huge majority of whom were the "dekulakized," who had been stripped of all their property and deported to inhospitable areas, such as the subarctic Northern Territory (Severnyi krai), the northern Urals, the Narym region in western Siberia, and northern Kazakhstan; and (2) the forced-labour camp inmates.

The tragic fate of the "special resettlers" has been amply described in detail in remarkable collections of documents and monographs (Danilov and Krasil'nikov; Shashkov; Krasil'nikov). Their losses as a result of starvation, epidemics, and exhaustion are staggering: 200,000-250,000 deaths in 1930-31 (11-14 percent of the 1.8 million deported during these two years); nearly 100,000 deaths in 1932 (8 percent of the remaining deportees); and more than 150,000 deaths in 1933 (14 percent of the group). Altogether approximately half a million spetspereselentsy died-that is, between one fifth and a quarter of the 2.2-2.3 million people deported during the years 1930-33. Infants and children were the most vulnerable, as many documents have underscored. (See, for example, RSFSR People's Commissar of Internal Affairs Vladimir Tolmachev's letter of 16 April 1930 to Dmitrii Lebed' [Dmytro Lebid'], vice-chairman of the RSFSR Council of People's Commissars, about the desperate situation of deported kulaks in the Northern Territory [Danilov and Berelowich 301-305].) The first wave of deportation $(600,000$ people in February-May 1930) resulted in a deadly "mass abandonment." The general chaos and the lack of co-ordination between the OGPU, which was responsible for transporting the deportees, and the local authorities in charge of their "installation" often resulted in the abandonment of tens of thousands of people in the middle of nowhere. In anticipation of the "second wave" of deportations (more than 1.2 million people in May-September 1931), a special Politburo Commission (presided over by Andrei Andreev in 1931 and Jānis Rudzutaks in 1932) was installed in order to rationalize, from an economic point of view, the exploitation of the spetspereselentsy; only twelve percent of the surviving deportees had been put to work by March 1931, and this, of course, hampered the grandiose "colonization plans" that the special resettlers were supposed to implement. Under the new provisions established by the Andreev Commission, the OGPU was to organize the transportation, housing, and feeding of the deportees and to allocate them to work as lumberjacks, miners, and in construction in conditions similar to those in forced-labour camps. This attempt to "rationalize" the deportation did not improve the deportees' fates. Death rates remained very high in 1931 and 1932 and exploded in 1933, after brutal cuts in December 1932 of rations allocated to deportees (lowered by 45-70 percent!). When, by chance, rations did arrive, a working adult received four to five kilos of wheat, 600-700 grams of fish, 
and three hundred grams of sugar per month. Children were entitled to 100-150 grams of rye bread per day. In 1933 one infant out of two, one child out of five, and one adult out of eight died in the "special settlements" (Krasil'nikov 124-25). Mortality was even higher for the new category of "undesirable elements" forcibly deported from a number of "regime cities" in the course of "cleansing operations" by police launched in the spring of 1933. The most striking example was that of the 6,100-6,700 persons deemed "déclassé and criminal elements" who were deported overnight on the eve of the May 1 celebrations from Moscow and Leningrad to Tomsk, and from there to the tiny island of Nazino four hundred miles upstream on the Ob River. By the end of June, more than four thousand had died from starvation, with no accommodations, tools, or food ever having been provided (Werth).

Epidemics and starvation also decimated the inmates of forced-labour camps. Between January 1930 and January 1934, the number of detainees in the "corrective labour camps" (ITL-ispravitel'no trudovye lageria) grew fivefold in four years, increasing from 95,000 to 510,000. This increase was particularly acute during the first three months of 1933, during the peak both of the repression and of the famine (the population of the ITL grew from 334,000 to 456,000 between 1 January and 10 April). The mortality rate (which was stable, around six percent per year during the years 193032) jumped to fourteen percent in 1933, when the camps' administrations registered more than 72,000 deaths.

In fact, as detailed studies of particular camps have shown, the mortality rate could be significantly higher. For example, in the Sazlag camp in Uzbekistan, which had 18,000 inmates, the camp's administration registered 4,700 deaths in 1932 and 4,900 in 1933. Such extraordinary mortality (one out of four prisoners died at the Buchenwald Nazi concentration camp in the course of 1942!) was explained by "food difficulties" (clearly a euphemism for starvation) and epidemics (Nakonechnyi 14; GARF, f. 9414, op. 1, d. 2740, l. 8.). In reality, the mortality was even higher: In February 1933, in order to house the huge number of prisoners pouring into the camp, the administration of the Sazlag camp set up a commission to determine which invalids could be released. That "unloading commission" (razgruzochnaia kommissiia) freed in extremis 2,300 invalids, and ill and emaciated prisoners unable to perform any work. A third of them died before the end of March. Camp mortality in 1933 was exceptional (it would be surpassed only in 1942 and 1943), as was the situation in all of the USSR. Like many other Soviet subjects, a great number of the people sentenced and sent to camps in 1932 and 1933 were subjected to "shock therapy" and were in very poor physical condition for building the "radiant future." 
Before concluding, I would like to return to the fundamental question of the "usefulness" or "superfluousness" of Soviet subjects in times of famine. This basic principle was also applied when the state provided starving people with minimal help. At the peak of the 1933 famine a small number of people received such negligible assistance. Its aim, as stated in secret instructions, was "to secure the successful achievement of the spring sowing campaign... A minimal food allowance is to be distributed solely to those who conscientiously participate and have already started working" (Pyrih). Numerous instructions delineated the bureaucratic rules for the differential feeding of the collective farmers "in accordance with the progress of the preparation for sowing and the fulfillment of sowing targets." For each kolkhoz, a troika consisting of the head of the raion's soviet, Party secretary, and a plenipotentiary sent by the soviet were to determine which collective farmers needed help on the basis of a list the board of the kolkhoz provided. A differentiated distribution of 100-400 grams of flour per workday (a tractor driver could receive three to four times more than an ordinary, non-qualified kolkhoznik) was to take place every five days, and only on the basis of days worked. To prevent "levelling" (uravnilovka), no meals were to be issued communally to groups working in the field. Kolkhozniks who did not fulfill the norm were to be denied food immediately. On days of rest, no bread was to be distributed (this provision was harsher than ones in force in the labour camps!) (Podkur 434).

Many instructions singled out the categories of survivors entitled to receive just enough assistance to allow them to work, according to their "social usefulness" (tractor drivers, brigade leaders, and accountants were at the top of the list, followed by kolkhozniks who had logged a high number of workdays during the previous year. Among individual farmers, only those who had joined the kolkhoz were included among those to receive aid. Reports by newly appointed officials of the political departments of the machine-tractor stations (politotdely MTS) provide a wealth of information on the way this administration, full of GPU and Red Army personnel, used incredibly harsh means to force starving people back to work: only those who were still able to work were fed. Some reports hint at a practice that cannot be qualified otherwise than as a form of "selection": every morning politotdel officials carefully evaluated the physical ability of those fit enough to be fed and put to work for the day (Podkur and Vasyl'iev 434-37). Thus the Leninist principle "He who does not work shall not eat" was implemented in its crudest form, leaving only the fittest and strongest to survive.

In his 10 June 1932 letter to Stalin, Hryhorii Petrovs'kyi, chairman of the All-Ukrainian Central Executive Committee, wrote: "I visited many villages and saw a number of swollen and starving people.... Women were 
crying, even men sometimes. 'Why have you created this artificial famine?' they asked. 'We had a harvest, why did you confiscate it all? Even under the old regime no one would have done this!'” (Vasyl'iev and Shapoval 213).

The testimonies of survivors, whether collected in the 1950s, 1980s, or 1990 s, point to the fact that the famines of the 1930s were unanimously perceived as fundamentally different from previous ones: they were "manmade," "artificial" famines, during which all the traditional ways peasant society had, over the centuries, survived in time of dearth and hungereating available livestock, asking better-off neighbours for help, and leaving the village to find a job in town-no longer worked.

We also know precisely what Stalin and his entourage, who were informed daily about the situation in the entire USSR, thought of the peasants and famines. Stalin considered the peasants resisting grain or meat procurements to be at war with the Soviet state. In his 6 May 1933 reply to the letter Mikhail Sholokhov wrote to him on 4 April 1933 detailing the atrocities local Bolshevik officials committed against the peasants, Stalin dropped all references to social categories: "the respected farmers of your raion (and not only your raion) conducted "ital'ianka" (sabotage!) and were not averse to leave the workers, [and] the Red Army without grain. The fact that the[ir] sabotage was tacit and seemingly harmless (without bloodshed)... does not change [the fact] that the respected farmers were in essence waging a 'silent' war against Soviet power. War by starvation, Comrade Sholokhov."2

During his speech to the Plenum of the Party's Central Committee on 27 November 1932, Stalin stated that the Soviet state had to respond to the peasants' "tikhaia sapa" (war on the sly) with a "sokrushitelnyi udar" (knock-out punch). The weapon of famine was to be that punch, teaching the peasants the lesson that the state was stronger and would impose its will and force them to work on the collective farms. That the ruling Bolshevik elite supported this "function" of the famine is clearly revealed in Stanislav Kosior's letter of 15 March 1933 to Stalin: "The unsatisfactory preparation for sowing in some of the worst affected areas clearly shows that hunger has not yet taught many collective farmers good sense" (Pyrih 771).

Certainly, the Soviet famines were related to economic matters: those who suffered most were the peasants, herders, and their families in areas considered to be strategic for grain and meat procurements. Politics were

${ }^{2}$ Archive of the President of the Russian Federation, f. 3, op. 61, d. 549, 1. 194. 
always essential and came first in the USSR. This explains the terrible fate of the Ukrainian peasantry, which was targeted both as the grain producers of the main "bread basket" of the Soviet Union and as the bearers of "Ukrainian nationalism" supposedly linked to "foreign imperialism," and of the Kazakh herders, who were targeted both as the main providers of meat and as "superfluous elements of a primitive, unredeemable way of life" that had to be eradicated in the course of history.

What was at stake was a new, cynical, and brutal relationship between the "socialist" state and its subjects based on a new hierarchy and callous indifference to mass death. If those at the bottom of the hierarchy were supposed to die-that is, the deported kulaks and "socially harmful elements," people sent to labour camps, but also "superfluous elements" such as the disenfranchised "lichentsy" or people of the past ("byvshie"), not to mention the "lazy kolkhozniks" - did it really matter? In a period of hardship during the construction of a new world, the "less valuable" had to be sacrificed in order to save the "most valuable" for the state.

\section{Works Cited}

Archive of the President of the Russian Federation. Print.

Danilov, V[iktor] P. and A. Berelowich, eds. Sovetskaia derevnia glazami VChK-OGPUNKVD, Vols. 1-2 (1924-1929). Moscow: Rossiiskaia politicheskaia entsiklopediia, 2000. Print.

Danilov, V[iktor] et al, eds. Tragediia sovetskoi derevni: Kollektivizatsiia $i$ raskulachivanie: Dokumenty i materialy v 5 tomakh, 1927-1939. 5 vols. Moscow: ROSSPEN, 1999-2006. Print.

Danilov, V. P., and S. A. Krasil'nikov, eds. Spetzpereselentsy v Zapadnoi Sibiri: 1930vesna 1931. Novosibirsk: Nauka, 1992. Print.

Danilov, V, P., and I. E. Zelenin. "Organizovannyi golod: K 70-letiiu obshchekrestianskoi tragedii." Otechestvennaia istoriia, 5 (2004): 97-111.

GARF. Gosudarstvennyi arkhiv Rossiiskoi Federatsii. Moscow. Print.

Graziosi, Andrea. "The Soviet 1931-1933 Famines and the Ukrainian Holodomor: Is a New Interpretation Possible, and What Would Its Consequences Be?" Hunger by Design: The Great Ukrainian Famine and Its Soviet Context. Ed. Halyna Hryn. Cambridge, MA.: Ukrainian Research Institute, Harvard University, 2008. 1-19. Print.

Kessler, Gijs. "The 1932-1933 Crisis and Its Aftermath beyond the Epicenters of Famine: the Urals Region." Hunger by Design: The Great Ukrainian Famine and Its Soviet Context. Ed. Halyna Hryn. Cambridge, MA: Ukrainian Research Institute, Harvard University, 2008. 117-29. Print.

Krasil'nikov, Sergei. Serp i Molokh: Krestianskaia ssylka v Zapadnoi Sibiri v 1930-ye gody. Moscow: ROSSPEN, 2003. Print.

Lewin, Moshe. La formation du système soviétique. Paris: Gallimard, 1985. Print.

Maksudov, Sergei. "Dehumanization: The Change in the Moral and Ethnic Consciousness of Soviet Citizens as a Result of Collectivizations and Famine." 
After the Holodomor: The Enduring Impact of the Great Famine on Ukraine =Harvard Ukrainian Studies 30 (2008). Ed. Andrea Graziosi, Lubomyr Hajda, and Halyna Hryn. Cambridge, MA: Ukrainian Research Institute, Harvard University, 2013: 123-48. Print.

Martin, Terry. The Affirmative Action Empire: Nations and Nationalism in the Soviet Union, 1923-1939. Ithaca: Cornell UP, 2001. Print.

Nakonechnyi, M. Iu. "Sazlag OGPU-NKVD kak lager permanentnoi katastrofy.” Ms.

Osokina, Elena. Za fasadom "Stalinskogo izobiliia": Raspredelenie i rynok v snabzhenii naseleniia v gody industrializatsii, 1927-1941 Moscow: ROSSPEN, 1998. Print.

Pianciola, Niccolò. "The Collectivization Famine in Kazakhstan, 1931-1933.” Hunger by Design: The Great Ukrainian Famine and Its Soviet Context. Ed. Halyna Hryn. Cambridge, Mass.: Ukrainian Research Institute, Harvard University, 2008.10316. Print.

---. Stalinismo di frontier: Colonizzazione agricola, sterminio dei nomadi e costruzione statale in Asia Centrale (1905-1936). Rome: Viella, 2009. Print.

Podkur, Roman, and Valerii Vasyl'iev, eds. Holod ta Holodomor na Podili, 1920-1940 rr.: Zbirnyk dokumentiv ta materialiv. Vinnytsia: Derzhavna kartohrafichna fabryka, 2007.

Pyrih, Ruslan, ed. Holodomor 1932-1933 rokiv v Ukraini: Dokumenty i materialy. Kyiv: Vydavnychyi dim “Kyievo-Mohylians'ka akademiia," 2007. Print.

Rossman, Jeffrey. "A Workers' Strike in Stalin's Russia: The Vichuga Uprising of April 1932." Contending with Stalinism. Ed. Lynne Viola. Ithaca: Cornell UP, 2002. Print.

Shashkov, V[iktor] Ia. Raskulachivanie v SSSR i sud'by spetspereselentsev, 1930-1954 gg. Murmansk: Murmanskii gosudarstvennyi pedagogicheskii institut, 1996. Print.

Vasyl'iev, Valerii, and Iurii Shapoval, eds. Komandyry velykoho holodu: Poizdka V. Molotova i L. Kahanovycha v Ukrainu ta na Pivnichnyi Kavkaz. 1932-1933 rr. Kyiv: Heneza, 2001. Print.

Viola, Lynne. Peasant Rebels under Stalin: Collectivization and the Culture of Peasant Resistance. New York: Oxford UP, 1996. Print.

Werth, Nicolas. Cannibal Island. Princeton: Princeton UP, 2007. Print. 
(c) 2016 East/West: Journal of Ukrainian Studies (ewjus.com) ISSN 2292-7956 Volume III, No. 2 (2016) 